\section{Políticas de la Música Bailable en Colombia: una aproximación al regionalismo 'paisa' a partir de sus estéticas musicales, dancísticas y festivas}

\author{
América Larraín \\ Universidad Nacional de Colombia/ Medellín, Colombia \\ aylarraingo@unal.edu.co \\ ORCID: https://orcid.org/0000-0002-5783-2815
}

DOI

http://DX.DOI.ORG/10.11606/ 1678-9857.RA.2021.184477

Este artículo es el resultado de una investigación sobre la relación entre las estéticas

Colombia, musicales y dancísticas y el regionalismo en Colombia. Se trata de una aproximación al caso del departamento de Antioquia, cuyos habitantes son conocidos coloquialmente como 'paisas'. Aquí, busco responder inquietudes sobre la forma en que determinadas maneras de hacer música, danzar y festejar, conforman un repertorio estético regional que se ha diseminado por el país, particularmente a partir de la década de 1960, construyendo lo que podría pensarse como un tipo de hegemonía corporal, que tiene despliegues políticos. En un primer momento, explico qué son los 'paisas', para después presentar el concepto 'Música Bailable', y, de esta forma, situarlo como punto de partida de la reflexión, siguiendo las descripciones de autores que han estudiado el tema con profundidad. En las siguientes secciones del artículo, busco mostrar cómo esa forma 'paisa' se ha diseminado a lo largo del país mediante la música, la danza y la fiesta, favoreciendo, lo que me parece, podría considerarse una hegemonía estética que se extiende al ámbito del ejercicio político. Finalmente, ofrezco algunas conclusiones abiertas para dar continuidad a las reflexiones aquí iniciadas, a partir de nuevas investigaciones e hipótesis que eventualmente puedan contribuir al tema.

Politics and Música Bailable in Colombia: an approach to 'paisa' regionalism from music, dance and aesthetics 


\section{INTRODUCCIÓN}

Este artículo indaga por las relaciones entre algunos soportes estéticos (música, danza y fiesta, particularmente) y su vínculo con el proyecto regionalista antioqueño, en Colombia, buscando entender cómo las estéticas allí producidas, han modelado la forma en que a partir de esa versión oficial de lo 'paisa', se han pensado, construido y reproducido en Colombia ciertos modos de ser/estar en diversos espacios, inclusive en la fiesta y en la danza'.

En este trabajo dialogan diferentes escenarios, a modo de una etnografía multisituada o multilocal, donde los principales focos de la investigación fueron festividades populares próximas a Medellín (capital del departamento de Antioquia); fiestas de clubes privados en Medellín, entrevistas a personajes destacados de la escena musical regional, trabajos recientes y reconocidos sobre el tema, así como parte de la producción de la casa musical Discos Fuentes.

Me refiero a etnografía multisituada o multilocal, claramente haciendo alusión al concepto que Marcus popularizó a finales de la década de 1990, donde la definía como una modalidad de investigación que examina la circulación de objetos, identidades y significados que no pueden ser abordados en un único ambiente. Una etnografía multisituada o multilocal, construye trayectorias inesperadas, al buscar

1 | Es importante advertir, que esta perspectiva no pretende generalizar las estéticas presentes la región antioqueña o a los llamados 'paisas' como un todo, sino señalar una versión oficial que se ha instaurado en el escenario nacional como consenso, a partir de aspecto específicos que discutiré con mayor profundidad adelante. De hecho, es bueno recordar que Colombia es un país muy diverso y que, en el último censo poblacional, 0,006\% de los entrevistados declaró ser rom (gitano);

$4,4 \%$ indígena; $9,34 \%$ negro, mulato o afrocolombians, incluyendo palenqueros y raizales de San Andrés y Providencia. (DANE, 2018). las conexiones y asociaciones de su objeto de estudio, a través y dentro de múltiples lugares (Marcus, 2001).

En este trabajo, no existe un escenario único de observación y análisis. Por el contrario, hay un intento por mostrar los hilos invisibles que conectan diferentes dimensiones relacionadas con los procesos sociales, políticos y simbólicos regionales que se sitúan en diferentes escalas y fluctúan entre lo local (la región) y lo global (la nación y el mundo). Es ese tránsito entre soportes, temas y contextos, lo que me lleva a considerar este trabajo algo cercano a una etnografía multisituada o multilocal.

A partir de los datos consignados, esta reflexión busca aportar elementos para comprender el regionalismo paisa en Colombia, teniendo como eje las estéticas que son reproducidas como discursos locales, y que son empleadas como índices de identidad o pertenencia; como modos de adscripción a ese territorio y grupo específicos.

Finalmente, a partir de esta aproximación, busco entender las dinámicas políticas actuales en Colombia, pues considero - no es fortuito - , que la representatividad de esta región haya sido determinante en la definición de los rumbos del país en los últimos tiempos, mostrando una tendencia hacia posiciones políticas más conservadoras, próximas de la derecha, como se reveló de forma clara electoralmente en por lo menos tres escenarios recientes que presentaré con más detalle adelante.

Me interesa, de este modo, pensar todas estas manifestaciones estéticas como actos de poder en sí mismos, pues inciden y modelan las relaciones de las regiones 
y comunidades en Colombia, reificando ciertos mitos nacionales, donde los 'paisas' cuentan con un lugar de privilegio que incide claramente en las relaciones políticas en el país.

Hacer una revisión exhaustiva del contexto sociopolítico de Colombia, excede las pretensiones de este artículo. Sin embargo, frente a la necesidad de familiarizar al lector con algunos referentes centrales de la historia reciente del país, me permitiré hacer las siguientes claridades:

Aquí presento una reflexión sobre la relación entre soportes estéticos y política, teniendo como base eventos originados en la década de 1960, un periodo que, en el escenario global, estuvo marcado por el fin de las Grandes Guerras y el inicio de la Guerra Fría. Los impactos de este contexto sobre los soportes estéticos de los que hablaré, podrían ser similares para otros casos de América Latina y estar relacionados, por ejemplo, con la necesidad de cohesión e identidad al interior de las naciones, así como con la intensificación de la oposición entre discursos y posturas políticas de derecha y de izquierda.

Con todo, es pertinente destacar que Colombia tiene particularidades respecto a otros países de la región, pues desde la década de 1940, enfrenta una historia de violencias sucesivas, incluyendo una guerra interna no declarada, que, aunque con intentos de finalización formales, como los recientes acuerdos de paz firmados entre el gobierno nacional y las FARC-EP (2016)2 , continúa manifestándose mediante el asesinato selectivo de líderes sociales y excombatientes, así como en el reagrupamiento de fuerzas armadas al margen de la ley.

La lucha por la expansión territorial y por el dominio de áreas estratégicas para la explotación minera y para el narcotráfico, también han marcado la historia nacional. Además de la gran riqueza natural que le ha valido el título de segundo país más biodiverso del mundo ${ }^{3}$, Colombia es el país con mayor número de desplazados, superando a Siria. En 2019, la cifra era de 7'816.500 personas que habían huido de sus hogares por la violencia. La mayor parte proviene de los departamentos de Norte de Santander, Nariño, Chocó y Antioquia ${ }^{4}$.

Colombia, como otros países, vive realidades muy heterogéneas en cada región. Este ha sido uno de los aspectos que cimienta la pugna regional entre los centros andinos - sinónimo de desarrollo, poder económico y político - y las periferias, selvas y litorales, que siempre han sufrido una baja o nula presencia del Estado. Es pertinente resaltar que buena parte de las fricciones entre regiones corresponden a una jerarquización marcadamente racista, que ha caracterizado la historia del continente. Los soportes estéticos sobre los que trato en este artículo, dan cuenta de ello.

Música y danza han sido manifestaciones centrales en la construcción de los relatos nacionales, y en esa medida, evidencia de los procesos históricos que los han consolidado. Apropiación, depuración y transformación, son un primer
2 |Ver más en la cartilla pedagógica del acuerdo final: https://www.cancilleria gov.co/sites/default/files/ cartillaabcdelacuerdofinal2.pdf (revisado el 2 de junio de 2020)

3 | Ver más en: https:// minciencias.gov.co/ sala_de_prensa/colombia-elsegundo-pais-mas-biodiversodel-mundo (revisado el 2 de junio de 2020)

4|Ver más en: https:// www.elespectador.com/ colombia2020/pais/colombiael-pais-con-mas-desplazadosdel-mundo-articulo-866644 (revisado el 2 de junio de 2020) 
momento de dichos procesos; el segundo, la puesta en escena y la repetición — hasta olvidar de dónde vino - (García, 2016b). Ha sido bajo tal dinámica que en Colombia, música y danza - aunque no de forma exclusiva - , han sido un escenario donde se han consolidado las asociaciones y el lugar de lo indígena y lo afro en las jerarquías nacionales.

\section{LOS 'PAISAS'}

'Paisa'5 es el gentilicio o patronímico para las personas de la región del eje cafetero ${ }^{6}$ y del departamento de Antioquia en Colombia. Los 'paisas' son vistos y reconocidos como grandes colonizadores y desbravadores. Su gesta expansora es considerada uno de los eventos centrales del SXIX en Colombia. Este "espíritu colonizador" no se detuvo allí, pues en décadas recientes, han venido ocupado tierras a lo largo del país.

Pero los 'paisas', no solo son reconocidos en términos de expansión territorial, sino también por su audacia para los negocios, por ser grandes emprendedores, muy religiosos (católicos), y en la jerga local, 'berracos'7. Todo esto haría parte de un consenso construido y reforzado a lo largo del siglo XX por los intelectuales locales da la región (Larraín y Madrid, 2020).

Una parte importante de esas asociaciones se encuentra amarrada a la llamada Colonización Antioqueña. Este hecho ha sido ampliamente estudiado y descrito por investigadores que, desde perspectivas diferentes, señalan con cierto consenso, que se trató del mayor emprendimiento en la historia reciente de la región (finales del siglo XVWI y principios del XX). De cualquier forma, esta versión de lo 'paisa' no se reduce a textos, pues en el ámbito de las artes hay ejemplos notables como el cuadro "Horizontes" (1913), de Francisco Antonio Cano, que es visto como el emblema iconográfico de la Colonización Antioqueña.

Arcila Estrada (2006), esboza algunas ideas construidas por los escritores antioqueños del siglo XIX respecto a lo que se configuró como el discurso común de los modos de ser, del caráctery del temperamento de los antioqueños. Según señala, la construcción narrativa que hicieron los intelectuales antioqueños de los orígenes de su pueblo, se funda en un relato que tiene en el escarpado paisaje de montaña su principal protagonista, y, como consecuencia de ello, se reitera la tenacidad y el valor requeridos para enfrentar un medio tan agreste y hostil. $\mathbf{5}$ | No existe un consenso entre los investigadores sobre el origen de este vocablo, por tal motivo no ofrezco datos al respecto. Sin embargo, por la evidente semejanza, muchos sugieren que se trata de una contracción de la palabra 'paisano', es decir, coterráneo o del campo.

6| Este adjetivo se refiere a la valentía, coraje y audacia. En algunos textos aparece con la grafía "verraco".

7| Este adjetivo se refiere a la valentía, coraje y audacia. En algunos textos aparece con la grafía "verraco". 


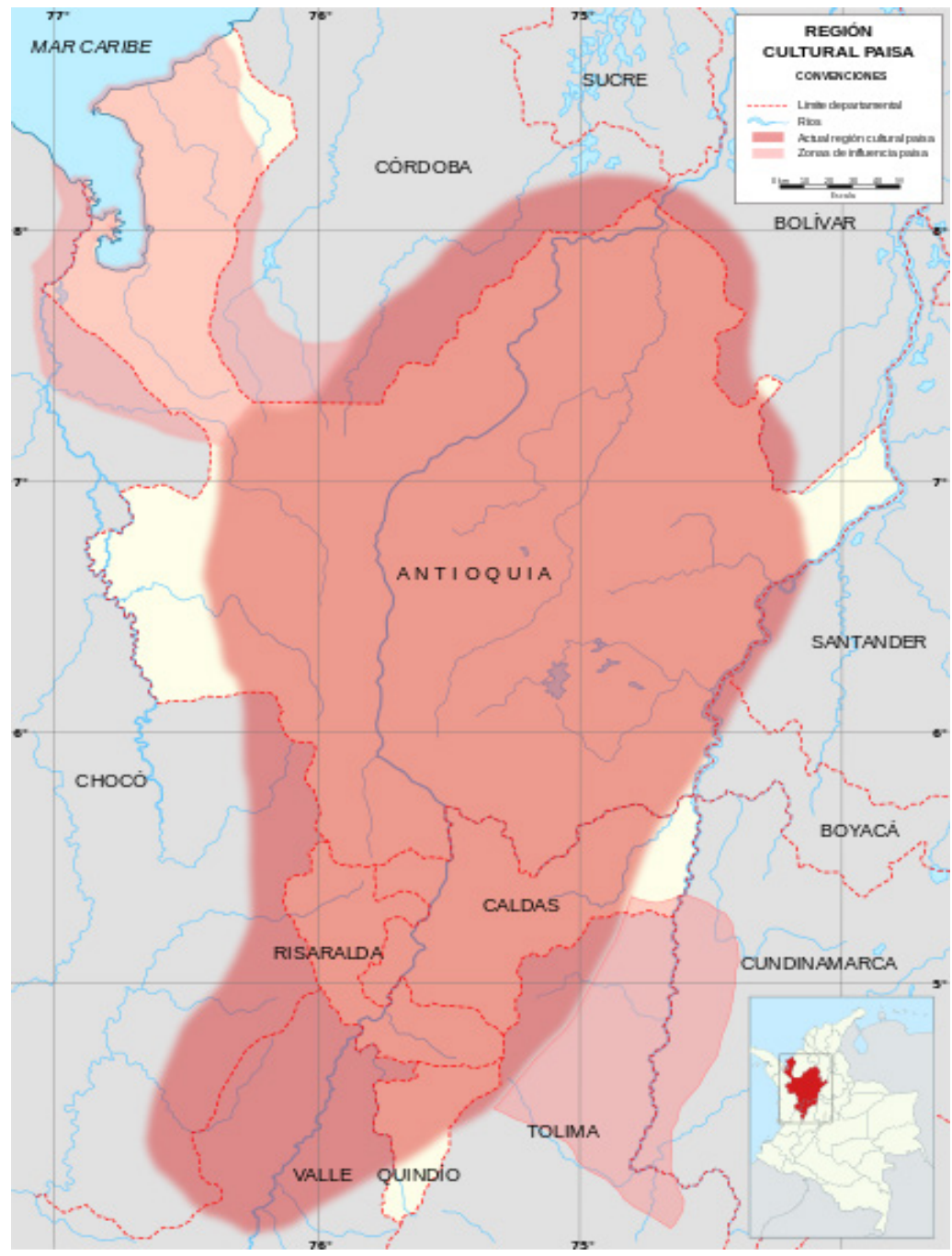

Imagen 1: Región cultural 'paisa' (2012)

En dicho relato, los colonos salieron victoriosos de las dificultades del entorno, lo que les habría permitido cimentar los sentimientos de orgullo y valoración de ese pretendido carácter dinámico y emprendedor con el que son caracterizados (:40) Este motivo, como muestra la autora, va a ser reiterado constantemente en los escritos históricos y sociológicos de los siglos XIX y XX.

Es pertinente destacar que la presencia indígena (población nativa) y negra (población esclavizada), son completamente excluidas de esas narrativas y relatos oficiales, haciendo que el paisaje sea generalmente descrito como un lugar deshabitado y no como un lugar del que fueron expulsados y/o exterminados sus habitantes originarios.

Podría decirse que existe un consenso nacional, más o menos estable, que considera verdades algunas de las aseveraciones respecto a las características que son atribuidas a cada grupo regional. Al hablar de costeños, paisas, opitas, caleños o pastusos ${ }^{9}$, se evocan imágenes - muchas veces caricaturizadas - de los habitantes de diferentes regiones del país. El estereotipo del 'paisa' en Colombia, se representa generalmente como el de un hombre de mediana edad, colonizador, católico, audaz
8| Imagen disponible en: https://es.wikipedia.org/ wiki/Archivo:Mapa_de_la_ Regi\%C3\%B3n Paisa.svg (revisado el 2 de junio de 2020)
9|Costeños (de los litorales pacífico y caribe, principalmente), paisas (del departamento de Antioquia y del eje cafetero), opitas (del departamento del Huila), caleños (de la ciudad de Cali, departamento del Valle) o pastusos (de la ciudad de pasto, departamento de Nariño, al sur del país). 
y ventajoso en los negocios, similar a Juan Valdéz, el personaje de la marca registrada de café colombiano. Este personaje podría pensarse como un intento de presentar la identidad regional, como identidad nacional, pues desde 1959, ha sido utilizado como ícono de la colombianidad.

Es llamativo que ese estereotipo sea tan marcadamente masculino, mientras, de otra parte, las mujeres 'paisas' son caracterizadas a partir de un ideal de belleza muy ligado a las estéticas impuestas por el narcotráfico de los años 80s y 90s. Dicha estética está asociada a la voluptuosidad derivada de la cirugía estética. No ahondaré sobre ese tema aquí, para mayor información ver los trabajos de Castañeda (2019) y Correa (2014).

Respecto a esta denominación 'paisa', existe un aspecto que es importante resaltar, y es que 'paisa' no se refiere apenas a los habitantes de una región, sino que también es una expresión utilizada en algunos contextos como modo de clasificación étnico. Así, además de ser el gentilicio o patronímico para las personas del eje cafetero y del departamento de Antioquia, en algunos lugares de Colombia, 'paisa', opera como categoría racial para referirse a las personas de piel más clara, o en general a quienes proceden del interior del país.

Lo que ocurre con los 'paisas' en el escenario colombiano, es muy semejante a lo descrito por Oliven (2006), respecto a los gaúchos para el caso brasileño. Según indica el autor, a los gaúchos les gusta remarcar y enfatizar su identidad regional respecto al resto del Brasil. En Colombia, aquellos identificados como 'paisas', también manifiestan con orgullo su procedencia y se esfuerzan por hacerla explicita a través de su acento y entonación marcados o por el uso de objetos distintivos que operan como señales, índices (diacríticos), por ejemplo: ropas típicas o souvenirs de los equipos locales de fútbol: Atlético Nacional y Deportivo Independiente Medellín (Larraín, 2012).

Según Oliven (2006), en el gauchismo, el predominio de la idea de tradición está relacionada con la construcción de identidades sociales. Se trata de una respuesta a una búsqueda de distinción cultural que tiene como uno de los puntos de partida, la resemantización del término que designa a esta población. Para el caso gaúcho, el nombre estaba asociado a "um tipo social que era considerado desviante e marginal, mas que foi apropriado, reelaborado e adquiriu um novo significado político, sendo transformado em símbolo de identidade regional" (:66). De igual manera ocurrió con los 'paisas', quienes según apunta Arcila Estrada (2006:52), eran descritos como "un mísero pueblo de provincia... vagos y perezosos".

También es pertinente resaltar la proximidad de los dos casos respecto a las referencias a la superioridad racial, moral y física, tanto de los gaúchos como de los 'paisas' y que tienen como contrapunto otros tipos regionales. El cuadro comparativo presentado por Oliven, donde expone los valores asociados a gaúcho y al baiano, es transferible de forma idéntica para pensar en Colombia la relación entre el 'paisa' y el 'costeño'10:

10| Habitante del litoral caribe o pacífico, cuya población es mayoritariamente de ascendencia africana. 


\begin{tabular}{|lll|}
\hline Gaúcho ('paisa') & $\mathbf{X}$ & Baiano (costeño) \\
Inteligencia & X & Estupidez \\
Trabajo & X & Pereza, fiesta \\
Ambición & X & Despreocupación \\
Astucia & $X$ & Simplicidad, ingenuidad \\
Agresividad & $X$ & Modestia, sumisión \\
Dureza, rigidez & $X$ & Tolerancia ("evasión") \\
Conservadurismo & $X$ & Libertinaje \\
Limpieza, orden & $X$ & Suciedad, desorden \\
\hline
\end{tabular}

(Oliven, 2006:142, traducción mía)

Se hace evidente cómo en ambos casos, tanto el 'paisa' como el gaúcho, son presentados como estereotipos únicos, cuyas características homogéneas serían transmitidas genética y culturalmente, fomentando un discurso étnico-regional, indispensable para la construcción de su identidad. Allí son comunes las alusiones a la sangre, a la raza y a los ancestros aguerridos: los colonizadores.

Así, según lo descrito por Oliven (2006), a pesar de que los contextos sean diferentes, el sustrato sobre el que esos discursos reposan, es sorprendentemente semejante. En ese sentido, podría afirmarse que tanto el gauchismo, como la antioqueñidad ${ }^{11}$ son casos exitosos de regionalismo, en la medida que logran transmitir reivindicaciones políticas que serían comunes a todo un estado, en el caso brasileiro y a un departamento en caso colombiano. La continuidad y vigencia de esos discursos regionalistas indican que las significaciones producidas por ellos tienen una fuerte adecuación a las representaciones de las identidades respectivas (Oliven, 2006).

\section{MÚSICA BAILABLE: LAS REGIONES Y LA NACIÓN}

Para el caso colombiano, la música ha sido explorada en trabajos recientes por autores que, desde sus campos de estudio particulares, señalan la relevancia de diferentes sonoridades en la construcción de las versiones de la Nación. Por ejemplo: Bermúdez (2006, 2007); Blanco (2009); Figueroa (2009); Hernández (2014); Parra (2014, 2017); Pardo (2009); y Wade (1997, 2002, 2011), entre otros.

Concretamente respecto a la llamada Música Bailable, hay un consenso entre investigadores que muestran que se trata de un rótulo a partir del cual en Colombia se han definido los géneros que abarcan las variaciones melódicas y rítmicas de la Música Costeña o Música Tropical12 (Wade, 2002). El nombre sirve también para identificar aquello que coloquialmente fue denominado chucu-chu$\mathrm{cu}^{13}$, género que tuvo en la casa discográfica Discos Fuentes y en la ciudad de Medellín, la cuna y el escenario propicio para su producción y circulación (Wade, 2002; Pardo, 2009; Parra, 2017).

11 | Es importante señalar que existe una semana del calendario del mes de agosto que, por ley, se dedica a celebrar la 'antioqueñidad' Durante esta semana, que coincide con la principal festividad de Medellín (La Feria de las Flores), instituciones educativas realizan actividades conmemorativas que exaltan el mencionado ethos regional.

$\mathbf{1 2}$ | Esta denominación se refiere principalmente a géneros como la cumbia, el vallenato, el porro y el fandango.

13| "Músicas Costeñas", interpretadas con instrumentos eléctricos como bajos, teclados y guitarras (Pardo, 2009). Se trata, según Parra (2017), de una definición onomatopéyica que se le otorgó a la "Música Tropical Bailable", en la década de 1960 en Medellín. 
Es importante resaltar que a pesar de la denominación genérica chucu-chucu, este abarcaría algunos subgéneros o variaciones de géneros, tales como: el porro, el paseo, la cumbia y la salsa. Todos estos diferentes de sus versiones "más tradicionales" y que comparten la misma base instrumental, predominantemente eléctrica: bajos, teclados, guitarras y su principal característica acústica: el güiro o raspa.

Según Parra (2017), el chucu-chucu sería resultado del proceso de adaptación funcional de ciertas herencias sonoras del caribe en contextos urbanos de carácter popular, configurados por dinámicas sociales que estaban ligadas a formas de consumo y búsquedas artísticas. Seria además un género, histórica y geográficamente situado en la ciudad de Medellín, que se encuentra ligado profundamente a la historia reciente de la región, a los cuerpos y afectos que encuentran en estas estéticas una piedra angular de cohesión.

Vale la pena mencionar que, en la región estudiada, existen otros géneros importantes que constituyen el repertorio "tradicional paisa". Por ejemplo, la llamada Música Parrandera (Bermúdez 2006; Duque, 2018). Sin embargo, en este trabajo me concentraré en la Música Bailable o chucu-chucu, pues estas sonoridades cuentan con mayor difusión y visibilidad en el escenario colombiano, pudiendo ser consideradas inclusive músicas nacionales. La Música Parrandera es un género mucho más local, con poca difusión y presencia fuera del circuito regional.

Respecto al chucu-chucu, la revisión realizada por Parra (2014, 2017), es muy valiosa y pertinente, pues el autor establece una línea cronológica de los hechos que permitieron el surgimiento y ascensión de este género, facilitando al lector la comprensión del entorno histórico, social y político que sirvió de cuna a lo que hoy es reconocido como Música Tropical Bailable o chucu-chucu. Según argumenta, Medellín era una localidad que, para inicios del siglo XX, pasó por una serie de tránsitos e intercambios intensos. Se trataba de una ciudad que, en sus palabras, se proyectaba textil en el plano industrial, y literaria en el plano intelectual. Para la década de 1950, Antioquia y su capital Medellín, no contaban con un discurso regional bien establecido.

Un momento central de la historia de este género musical, tuvo que ver con Lucho Bermúdez, reconocido músico nacido en Carmen de Bolívar — región caribe - quien habría encontrado en Medellín, un escenario muy rico para consolidar su carrera como músico ${ }^{14}$. Llegó a vivir a la ciudad en 1948, donde trabajó como músico y director de orquestas de hoteles y clubes privados durante más de 15 años. Su contribución a la música nacional es considerable, pero puede resumirse grosso modo por el hecho de haber introducido códigos procedentes del folclore 'costeño' colombiano, a partir de configuraciones musicales norte-americanas heredadas del jazz, junto con cadencias del interior - de la región andina.

Lucho Bermúdez habría llevado a ámbitos de élite la música del caribe -otrora desdeñada-, llevando consigo, también la danza. Sin embargo, la danza — ahora de

$\mathbf{1 4}$ | Mayor información sobre la vida de este célebre músico, puede servista en el documental "Lucho, el documental", producido por Señal Colombia (ver en: https://www.youtube.com/ watch?v=uEWCnFjnjXs -revisado el 2 de junio de 2020-). 
salón - , fue alejándose de las cadencias y formas rurales del caribe que son los ejes fundamentales de estos ritmos. Una de las importantes contribuciones de Bermúdez, habría sido justamente reformular las condiciones de percepción de los ritmos y valores 'costeños' para un público más extenso, procurando una proyección internacional, "blanqueando" la música, haciendo que fuera más digerible para el gusto de las élites urbanas segregacionistas. Lucho Bermúdez habría abonado el terreno para lo que vendría después. Otros músicos que hicieron propuestas similares fueron Pacho Galán y Edmundo Arias (Parra, 2014).

Esllamativoquealseñalarlas contribuciones demúsicoscomo Lucho Bermúdez, a la transformación de las sonoridades costeñas, el foco generalmente se concentra en la música. Aunque se trate de Música Bailable, se deja a la danza en un segundo plano. En ese sentido, sería interesante pensar hasta qué punto habría sido la danza el factor determinante para la modificación y transformación de los ritmos costeños; es decir, ¿cómo habría sido necesario ajustar dicha musicalidad para hacerla bailable según los cánones del lugar? Sugiero esto, siguiendo la pista de reflexiones como las de Hosokawa (1997), quien, para el caso de la salsa, expone las transformaciones de este género, como algo necesario para que pudiera bailarse en pareja.

Según señala el autor, otros géneros latinos, fueron remetrificados, pues de lo contrario sería imposible bailarlos en pareja. En esa medida, las consideraciones de Hosokawa, implicarían pensar una inversión: no se trataría tanto de la música orientando a la danza, sino de la danza modificando la música. Esta perspectiva desplaza el foco de lo exclusivamente auditivo, para considerar la música como una experiencia sensorial más amplia que implica lo corporal como un todo: sus afectos, sus historias y sus contextos.

Ya en la década de 1960 y gracias a los avances de la industria cultural nacional, particularmente la radio y la discografía, habría ocurrido lo que Parra (2014) denomina "la mayor revolución urbana tropical de la Música Bailable en Colombia". El autor subraya que dicha revolución habría tenido por protagonistas principalmente a los músicos antioqueños, que introdujeron diversas influencias al escenario local, creando un estilo nunca antes visto u oído.

En este proceso, se simplificaron al máximo las estructuras musicales, predominando los ritmos estables y fuertes ajustados a una batería, menos cadenciosos y más estáticos. Fue reducida también la instrumentación, y se comenzó a implementar el uso de respaldos eléctricos en guitarras y bajos, suprimiendo los clarinetes y cambiándolos por saxofones. Hubo además la incorporación de elementos de la música rural campesina como la raspa (güiro), responsable por el sonido que originó el nombre onomatopéyico de este género: chucu-chucu, o como muchos también lo llaman: "sonido paisa" (Parra, 2014).

Esa simplificación del sonido, según señala Parra (2014), impuso en la danza movimientos uniformes que, de acuerdo con el golpe de la raspa (güiro), configuran 
un territorio sensorio-motriz específico que revelaría un "ethos regional espacial". Este último aspecto es de especial interés a este estudio, por señalar justamente las relaciones entre: sensorialidad, movimiento, territorio: música, danza y etnicidad; y, por lo tanto: política.

La danza, es condición sine qua non de esta música, el propio nombre ya lo anuncia. Se trata de música "bailable", que existe para ser danzada. Aquí es evidente que la cuestión del desvanecimiento y la transformación de las estéticas asociadas a los ritmos "costeños", habría ocurrido principalmente en el plano de la danza: las cadencias y formas rurales no tenían lugar en los salones elegantes y elitistas donde músicos como Lucho Bermúdez los introdujeron, ni tendrían lugar donde posteriormente se presentaban los músicos que interpretaban el chucu-chucu. Es decir, no sólo se depuró la música, sino principalmente la danza, pues se acomodaron los movimientos y la experiencia sensorio-motriz, a los valores religiosos y principios morales que caracterizaban a Medellín en esta época: tradición y modernización; orden y progreso, una sociedad donde en palabras de Acosta, (2014), la música, el baile y las relaciones de pareja, estaban reguladas por la familia, la educación y la Iglesia; donde los jóvenes comenzaron a apropiarse de sus libertades para elegir sus estilos de vida.

Este podría considerarse un segundo movimiento de depuración y "blanqueamiento" de los elementos afro, indígenas y rurales presentes en la musicalidad de la época (Lucho Bermúdez habría encabezado el primer momento). Pero la cuestión no se agota aquí, sucede que la consolidación de ese relato musical y dancísitco que tuvo lugar en Medellín, nunca fue reivindicado como un aporte 'paisa' a la construcción de la versión oficial de la nación. Es decir, aun cuando en diferentes lugares del país hayamos crecido escuchando y bailando tales musicalidades, nunca estuvieron asociadas directamente a un origen 'paisa', a la región antioqueña o a la ciudad de Medellín y sí a los referentes e imaginarios del caribe. Retomaré este punto adelante.

El nombre chucu-chucu, surge definiendo con desprecio un hecho estético, además de ser una declaración abierta de la lucha simbólica por la hegemonía cultural entre tres regiones: Bogotá, Cali y Medellín. Surge en Cali en la década de 1970, como acusación a la ausencia de reflexión y de posicionamiento político de los 'paisas':

\footnotetext{
Nace, pues, desde un escenario minoritario -el academicismo folclorista costeño, por un lado y el intelectualismo urbano caleño, por otro-, nace con cierto resentimiento, nace en un contexto distante (es decir, desde la debida distancia) que empleaba toda su fuerza creativa para pensar algo que sus propios ejecutores no pensaban, porque lo estaban viviendo (Parra, 2014) (énfasis míos).
} 
Según Parra, ya Andrés Caicedo, escritor caleño, habría hablado del "sonido paisa", en su novela "Que viva la música", denunciando lo que estaba ocurriendo en el plano musical colombiano. El autor afirma que a través del chucu-chucu se define un estilo regional, una forma y unos movimientos que marcan ritmo; que separan un territorio del otro. En esa medida, el chucu-chucu sería la decodificación de un relato de región que estaba siendo impuesto por la creciente industria cultural -discográfica-en Medellín.

Parra habla de la resistencia cultural que habría habido allí por parte de los jóvenes 'paisas' que desarrollaron lo que él llama "un campo sonoro-discursivo", un lugar de hibridación y resistencia, configuradas por la adopción y adaptación. Él argumenta que el surgimiento de este género tendría que ver con la orfandad sonora y rítmica regional, que los llevó a crear su propio relato de origen para reconocerse allí. En palabras de Parra, se trata de: "Un folclor - o antifolclor, si se quiere- que se forma con residuos sonoros destinados al bricolaje cultural".

Es interesante señalar que estas reflexiones hacen referencia explícita al hecho de que este género opera como un campo de integración colectiva, siendo índice, ícono y símbolo de lo que Parra llama "ethos antioqueño". Tal como añade, se trataría de una territorialidad rítmica que expresa una coreografía corporal específica, gramatizando el espacio y produciendo marcas que constituyen hábitos y construyen hábitats, correspondiendo a expresiones atadas a las formas sensoriales y motrices que a su vez están ligadas con lo que el autor llama "infraestructuras osteo-musculares".

Para el caso descrito aquí, lo que se evidencia, es que la modelación de esa identidad 'paisa', en uno de sus pliegues, ha sido hecha a partir de la música y de la danza en una relación de aproximación, evitación y depuración de elementos estéticos de las músicas costeñas para constituir un modo propio ('paisa') de hacer música y moverse. Esto, revelaría una asociación étnica ligada a las preferencias musicales, oponiendo aquí a la región antioqueña y a los litorales caribe y pacífico (Wade, 2011). Dicha oposición es esbozada en el cuadro comparativo elaborado por Oliven (2006), donde se contrastan para el caso brasileño, gaúchos y baianos ${ }^{15}$.

Así, el chucu-chucu podría definirse como una transformación de ritmos caribeños para ser danzados de a par, teniendo como trazo central una corporalidad controlada, seria y firme que caracteriza el modo 'paisa' de moverse, esas "infraestructuras osteo-musculares" a las que se refiere Parra (2014). Expongo adelante algunos ejemplos de ello.

Ese modo 'paisa' se diseminó por el país, gracias a la difusión del chucu-chucu, aunque no fuera reconocido o reivindicado explícitamente como 'paisa' - antioqueño. Discretamente y sin bulla, se expandió como si fuera efectivamente un modo nacional, contraponiéndose, por ejemplo, al modo caleño ${ }^{16}$, donde predominaba en términos generales, la salsa de influencia puertorriqueña. $\mathbf{1 5}$ | Sin embargo, es pertinente mencionar que los grupos regionales en Colombia son mucho más amplios pero existe un consenso generalizado sobre la pugna histórica entre la costay los andes, dentro de los cuales la región antioqueña se ha destacado por jugar un rol de imposición y apropiación territorial.

16| De la ciudad de Cali, departamento del Valle del Cauca, suroeste de Colombia 


\section{LA DIFUSIÓN Y DISEMINACIÓN ESTÉTICA 'PAISA'}

En toda Colombia, antes de la década de 1960, la distribución discográfica y la radio ya facilitaban la circulación de manifestaciones musicales del mundo como el Rock n' Roll, el Twist, el Tango, el Danzón, el Son, el Bolero y las Rancheras. Pero Medellín era un lugar privilegiado para la música, por contar con la presencia de las más importantes casas de producción de discos en el país,

entre las cuales se encontraba, Discos Fuentes. Esta empresa, marcó los rumbos del desarrollo de lo que ha sido llamado música tropical y Música Bailable en Colombia. Según Wade (2002) y Bermúdez (2006, 2007), el surgimiento de esa categoría estaría ligado a la compilación musical conocida como '14 Cañonazos Bailables', lanzada 1961 por esta empresa, y que, desde entonces, se vende a la víspera de las festividades navideñas. Se trata de un disco que reúne los mayores 14 éxitos musicales del año en un solo álbum.

En ese sentido es pertinente resaltar que la propia idea de disco — como compilación - ya evidencia la existencia de un determinado campo sonoro (semántico), al incluir en un mismo formato una serie de melodías que se piensan y se construyen como semejantes a partir de determinados trazos. Discos Fuentes fue pionera en el país en la producción de este tipo de compilaciones.

En entrevista con su actual gerente general, Tony Peñaranda, y con Ángel Villanueva, director artístico, ambos coincidieron en que el nombre 'cañonazos' fue elegido por hacer referencia a retumbar, a tener un impacto. Esto habría fundamentado el título de la compilación, el hecho de ser canciones consideradas hits. Según indicaron, el número de pistas (14), implicó una importante innovación tecnológica, pues tradicionalmente los discos de vinilo, tenían 6 canciones por cada lado, totalizando 12. Sin embargo, buscando incluir un número mayor de canciones, se hicieron transformaciones técnicas que permitieron los "14 Cañonazos Bailables".

Es interesante resaltar que, para la década de 1960, Discos Fuentes contaba con una importante red de promotores que iba hasta las emisoras de radio y a los diarios para publicitar a los artistas que gravaban con ellos. Además, tenían distribuidores y vendedores al rededor del mundo, garantizando su presencia prácticamente en los cinco continentes. Esto, sin duda formó también una imagen de Colombia en el exterior, que tenía como uno de sus referentes principales las sonoridades divulgadas por esta empresa, así como las estéticas enunciadas en sus portadas. Así, desde Medellín, fueron modelados prácticas corporales e imaginarios visuales de la nación.
17| Ver en: https://www.elpais. com.co/entretenimiento/ cultura/cuando-en-cali-secensuro-la-salsa-de-richie-rayy-bobby-cruz.html (revisado el 2 de junio de 2020) 
Cuestiones de género y raciales se hacen evidentes aquí, pues como fue mencionado atrás, el chucu-chucu y de modo general la Música Bailable pasó por un proceso de blanqueamiento de las sonoridades negras. Esto fue muy claro en entrevistas donde me hablaron explícitamente del prejuicio que sufrían los músicos negros que venían a grabar en la ciudad, debido al odioy al racismo manifiestos por la población local, que quería su música, pero no su presencia. En referencia a esto, la expresión de uno de los más conocidos radio locutores de la ciudad, Hernán Darío Usquiano, fue: "ellos trajeron la melanina" a la música 'paisa', sin embargo, había gente que no podía ni verlos ${ }^{18}$.

Siguiendo lo planteado hasta ahora, podría decirse que uno de los momentos clave, donde esas marcas o trazos de la identidad antioqueña, pasan a servir como identidad nacional, ocurrió vía la Música Bailable y tuvo una relación directa con la circulación de discos de este género, concretamente con la compilación "14 Cañonazos Bailables", que ayudaría a modelar los rumbos musicales (estéticos) de la nación, en términos de una identidad sonora que evocaba al caribe, pero que aludía visualmente a una versión blanqueada de este. Además, es de resaltar, que al tratarse de una compilación musical que salía a la venta en las vísperas de navidad, las sonoridades allí presentes marcaron las celebraciones de fin de año de varias generaciones en el país, a tal punto, que en muchos contextos estas canciones son reconocidas como música navideña.

Hubo, de esta forma un importante impacto y repercusiones de la difusión y expansión de la Música Tropical Bailable o chucu-chucu, en el proyecto y construcción de una hegemonía 'paisa' en el plano político nacional. Se trata del 'paisa', travestido de nación, haciéndose evidente que lo político, para el caso colombiano - pero no exclusivamente - puede ser entendido desde los géneros musicales/dancísticos colombianos que han sido señalados como representativos del carácter nacional, constituyendo lo que hoy es considerado ampliamente en los escenarios nacionales e internacionales como una performatividad ${ }^{19}$ colombiana.

Me interesa resaltar que dicha construcción de esa versión nacional al modo 'paisa' o antioqueño, se instaló en el país de forma discreta, pues el apelo 'paisa' nunca fue explícito, y, por el contrario, se travistió de caribe ${ }^{20}$. Algo semejante ocurre
19| Utilizo aquí el concepto de performatividad, siguiendo su acepción en estudios de la danza, donde se aborda como un discurso del habla del cuerpo que se revela en el propio hacer artístico, constituyendo un "hacer" que es también "decir".

$\mathbf{2 0}$ | La reivindicación 'paisa' es relativamente reciente y tiene que ver con trabajos académicos como los de Parra $(2014,2017)$, que han revelado la importancia de esas musicalidades en la construcción de la identidad regional y su impacto en el contexto nacional. 
hoy con el reggaetón, género musical surgido en Puerto Rico y que cuenta con una importante presencia en América Latina. Medellín ha sido llamada recientemente la "meca" o capital mundial del reggaetón, por ser el más importante punto de producción y difusión de este género ${ }^{21}$. Sin embargo, llama la atención que ese título no es motivo de orgullo ni de exaltación respecto a la identidad 'paisa'. Es decir, no se ufanan de ello y, por el contrario, tal referencia es excluida por completo de los discursos regionalistas, que reivindican otras tradiciones como la rural, asociada a la Colonización y la industria textil, asociada a la modernidad. En el plano musical, por ejemplo, Medellín prefiere ser recordada como la ciudad donde murió Carlos Gardel. Esto puede deberse a que el reggaetón contradice los valores morales tradicionales asociados a la identidad regional y los aproximan más a referentes caribeños/costeños (recordando el cuadro de Oliven).

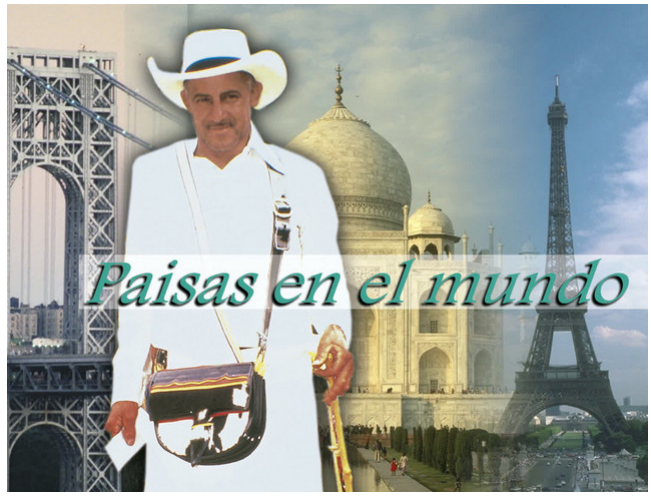

Carátula de una compilación de Discos Fuentes (2015), musicalidades que vienen siendo descritas. Percíbase el atuendo típico antioqueño (o paisa) del personaje..$^{22}$ que reúne algunos ejemplos importantes de las

\section{LA MÚSICA, LA DANZA Y LA FIESTA COMO DISCURSO REGIONAL Y NACIONAL ${ }^{23}$}

Era sábado, final de la tarde, y en un club particular de la ciudad de Medellín estaba comenzando un nuevo encuentro, una fiesta o "tertulia bailable". El Doctor Alberto Burgos (médico de profesión), su promotor y organizador, presidía el evento del que es fundador y que viene realizando mensualmente por más de 20 años. En esa ocasión la fiesta contaba con más de 300 asistentes.

Cuando lo contacté telefónicamente para conversar sobre el tema de este estudio, él se mostró muy dispuesto a dialogar. Siendo reconocido como uno de los grandes expertos melómanos de la ciudad y una verdadera autoridad respecto a la música regional, está acostumbrado a ser consultado con frecuencia y parece disfrutarlo. Conduce un programa radial y participa en diversas actividades del circuito musical en Medellín.

El doctor Burgos, insistió en que yo debía conocer su "tertulia bailable". Describió el evento como "un espacio orientado a personas mayores, donde se escucha y danza música de antes de la década de 1980, donde se danza la música nuestra, la música nacional" (énfasis míos). Subrayó que todos los asistentes de sus tertulias, sabían con anticipación que tipo de música iban a escuchar y a bailar: "nadie llega aquí pidiendo bachata o merengue", me dijo, exaltando el carácter de conocedores
21 | Algunas noticias sobre este asunto, pueden ser leídas en diarios de circulación nacional e internacional en los siguientes enlaces: https://www.bbc.com/mundo/ noticias/2013/11/131017 cultura_medellin_capital_ musical_colombia_jgc (revisado el 2 de junio de 2020). https://www.semana com/cultura/articulo/ medellin-la-meca-delregueton/551877 (revisado el 2 de junio de 2020)

22 Ver la lista completa de canciones en: https://open spotify.com/album/2rLYVRiBpo EG7L9nyjWooB (revisado el 2 de junio de 2020)

23 | Para una mayor aproximación a las dinámicas aquí descritas, sugiero al lector ver el documental "Cuando el Chucu Chucu se vistió de Frac" (Premio Simón Bolívar, 2014) https://www.youtube. com/watch?v=r1_RRyxjCCo (revisado el 2 de junio de 2020). 
(experts) de aquellos que frecuentan sus fiestas y, simultáneamente evidenciando un sistema clasificatorio entre la música nuestra y la que no considera como tal.

Una vez en la fiesta, pude percibir exactamente a qué se refería cuando me dijo "personas mayores". Calculo que el promedio de edad entre los asistentes, debía estar entre 60 y 70 años. En proporciones iguales hombres y mujeres, algunos informales y otros elegantemente vestidos, aguardaban el inicio oficial de la fiesta. Conversaban en sus mesas, dispuestas en torno de una pista de baile, comiendo pasabocas y bebiendo ron, aguardiente o cerveza. Según me había contado el organizador del evento, la realización mensual de esta fiesta era una de las actividades centrales en la vida de muchas de estas personas, quienes, al recibir su pensión, reservaban siempre el dinero para participar en la tertulia bailable.

La fiesta inició con la conferencia del doctor Alberto Burgos. El tema en esa ocasión, era la orquesta venezolana Los Blanco, que describió como "cinco hermanos negros con un cantante blanco que cantaba como negro". Su presentación combinaba explicaciones y audición de las canciones sobre las que hablaba, y claro: danza. La conferencia propiamente dicha demoró una hora, tras la cual inició la sucesión ininterrupta de música y baile que solo concluyó pasada la media noche.

Los asistentes se paraban para danzar en cada uno de los intervalos musicales. Algunos más diestros que otros, se lanzaban a la pista con sus parejas moviéndose siempre de acuerdo a los cánones de los géneros que se escuchaban: chucu-chucu, paso doble, bolero y hasta un twist, animaron a los presentes durante la noche. Sin embargo, el predominio del chucu-chucu, fue notable. Eso que antes él había llamado "música nuestra, música nacional", era el foco.

Los movimientos de los bailarines allí, podrían describirse de modo general como danza de pareja hete-
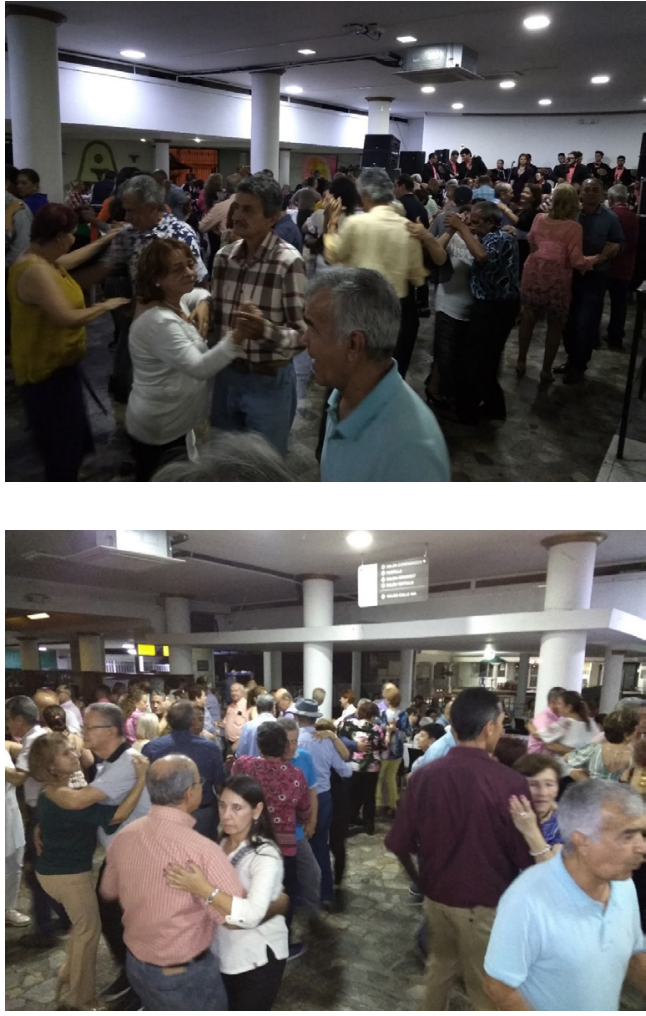

Tertulia Bailable, Medellín, 2019 Fuente: Autora rosexual: hombre y mujer, espaldas rectas, las manos derechas tomadas y suspendidas a la altura de los hombros. La mano izquierda de la mujer en el hombro del compañero, y la de él, en la cintura de ella. Un ligero movimiento de cintura y caderas que se balancean como resultado del 
desplazamiento lateral de los pies al ritmo de la música. Algunos giros y vueltas, a gusto de cada pareja.

Durante la danza en la pista, estas parejas establecían muy poco o ningún contacto visual, casi ninguno conversaba. Podría decirse que una atmósfera ascética caracterizaba el evento y los movimientos, a pesar de la aparente festividad de los ritmos que sonaban allí. La heteronormatividad reinante era reforzada en gestos como los de los hombres galantes invitando a danzar a las mujeres - diferentes de las parejas con las que habían asistido - y el recato femenino en los atuendos y en la complacencia con los hombres, al aceptar las invitaciones a bailar.

Repárese en las imágenes la corporalidad y gestos de los bailarines. Esta forma de danzar es peculiar, se diferencia de otras formas de danzar que pueden parecer similares, pero no lo son. En el chucu-chucu hay una cierta rigidez y estática del cuerpo que parece moverse por inercia; hay poco o ningún contacto visual entre los bailarines; los movimientos son simples, y como mencioné atrás, evocan una atmósfera ascética, sobria y moderada que no exige una gran competencia dancística. Es decir, no hay que ser un experto para hacerlo bien.

Se trata de un género que cuenta con mucha aceptación entre ciertos sectores de la población colombiana, particularmente mayores de 60 años. Aun así, es preciso señalar que existen tensiones y disensos importantes, por ejemplo, con Cali, tal como fue comentado atrás, y con el litoral caribe, donde en palabras de un nativo cartagenero: "si llegas a Cartagena a una fiesta y pones esa música, te sacan".

Cuando fui invitada a danzar por parte de algunos de los participantes asiduos de la fiesta, noté cuanto esas músicas y sus movimientos asociados eran familiares para mí. De alguna forma, mi cuerpo conocía el movimiento y percibía las diferencias sutiles de los ritmos que componen eso que vengo llamando chucu-chucu. No se trata de algo excepcional, pero si de algo importante, pues indica el conocimiento incorporado, un saber que no es apenas mío, sino compartido por un gran número de personas, y que se remite a las sonoridades y prácticas corporales que componen la historia colectiva de una nación. Mientras me movía y danzaba al ritmo de la música, percibí como esto no pasa por una racionalización del movimiento. No hay teoría allíy si un tipo de experiencia más parecida a aquello descrito por Pérez Bustos et al (2016) como un saber que pasa por el cuerpo, esos conocimientos que tienen el 'contacto' como fuente y lugar mismo de reproducción, y a las emociones suscitadas como punto de inflexión de las reflexiones.

De la misma forma, Hernández (2014) explica que en esos encuentros también se producen significados y asociaciones que con el tiempo se transforman en referentes culturales, lo que permite evocar imágenes y emociones que de cierta forma son compartidas. Esto permite entender, que determinados géneros que son reconocidos como músicas nacionales, tengan el potencial de modelar los cuerpos, en la medida en que se transforman en referentes que son compartidos y operan en
24 | Comunicación personal con colega de la "Escuela de Verano en Ciencias Sociales, University of Princeton - Universidad Nacional de Colombia. Pensar y hacer Ciencias Sociales en América Latina",Bogotá 2 - 9 de junio de 2019. 
el plano de esas "disposiciones incorporadas" de las que habla Bourdieu (2007 [1979]) para referirse al habitus.

Yo me atrevería a decir que en Colombia hay un habitus bailarín. Aquí la danza es fundamental como parte de las prácticas de socialización en los más diversos contextos. Se baila en cumpleaños, matrimonios, bautizos, fiestas empresariales, pero también se baila en el asado del domingo en casa, en los bares, en la calle. Es decir, no se trata de una manifestación sujeta exclusivamente a lo extra cotidiano, sino de algo que ocurre siempre que la música así lo disponga. Esto puede ser bien diferente en otros escenarios, inclusive latino-americanos, donde la danza ocurre exclusivamente en los momentos y lugares destinados para tal $\mathrm{fin}^{25}$.

Por su parte, García (2016b), habla de la danza como una práctica y actividad central de la experiencia social y personal de ser colombiano. La autora argumenta que la danza no sólo revela relaciones sociales, sino que es el propio nodo de la experiencia social, pues se trata de una forma de conocimiento colectivo. En sus palabras, se trata de una ortopraxis, concepto que remite a las "infraestructuras osteomusculares" mencionadas por Parra (2014).

Como ejemplo notable de la centralidad de la danza y de su relación con la política, podría referirme a la campaña del exalcalde de Bogotá, Enrique Peñalosa, donde el respaldo político se realizó en el escenario, mediante un baile que protagonizaron los aliados del momento, entre estos, el expresidente Álvaro Uribe. Lo llamativo es que uno de los aspectos por los que este evento hizo noticia, no fue propiamente la alianza o los apoyos políticos, sino por la falta de competencia del expresidente para acompañar la coreografía que ocurrió en el palco durante la campaña ${ }^{26}$.

Lo anterior es importante porque pone en evidencia la demanda y la expectativa del público nacional respecto a la exhibición dancística de sus personajes notables -tal como lo mostré en un artículo anterior, en relación con las coreografías de la selección colombiana de futbol (Larraín, 2015). Este episodio es singular, pues me remite al que relata Carcía (2016a), respecto al video en el que aparecía uno de los jefes máximos de las FARC, bailando con su compañera sentimental ${ }^{27}$. Él tampoco parecía muy diestro en la danza, aun así, esta "incompetencia" no quebrantaba su estereotipo de hombre "viril" con poder y al mando. Para Carcía, esto se explica en buena medida gracias a la asociación que existiría en Colombia entre ciertos géneros de danza y lo femenino; a la sexualización y racialización del movimiento de la mujer y al exitoso proceso de costeñización del país que hace parecer que la competencia dancística - en ciertos géneros - es dominio exclusivo de mujeres, hombres negros y mulatos (2016a: 89).

A partir de lo anterior, no sería descabellado sugerir, que el éxito del chucu-chucu en Antioquia, y su propagación en buena parte del país, se ha dado en cierta medida gracias a que no implica una gran habilidad técnica de los bailarines, y que, al danzar así, hombres y mujeres se mantienen próximos a los valores asociados a los estereotipos
25| Viví casi 10 años en el sur de Brasil, donde pude observar que la danza se circunscribe a escenarios y momentos previstos para tal fin. Durante el tiempo que permanecí allí, bailé apenas en bares y en el carnaval. Nunca ocurrió que en una fiesta se bailara-a excepción de las que organizaban amigos colombianos.

26 | Ver en: https:// www.youtube.com/ watch?v=JybxKPmXr3Y (revisado el 2 de junio de 2020)
27|Ver en: https:// www.youtube.com watch?v=lkqlh_icjY (revisado el 2 de junio de 2020) 
occidentales segregacionistas que han caracterizado el proyecto de nación en Colombia. En palabras de García (2016a): "el hombre civilizado, blanco, viril, educado, correcto, que toma decisiones, es exitoso, esto es: de "una sola pieza", ¿un tronco ${ }^{28}$ ?".

Tony Peñaranda, director ejecutivo de Discos Fuentes, relató una anécdota donde hacía referencia al hecho de que, para muchas personas del circuito musical de Medellín, el modo como se danzan géneros que remiten al caribe, evoca la danza del tango. Otra referencia a ese hecho apareció en la entrevista realizada a Alberto Burgos, quien mencionó que, a partir de 1968, muchos de los bailarines que participaban en el Festival Internacional de Tango de Medellín, tras las presentaciones oficiales del evento, se reunían en los bares de la ciudad para danzar la música local, lo que hacían a partir de los movimientos que conocían como bailarines de tango. Esto, según indicó, de cierta forma habría homogenizado los movimientos, creando códigos coreográficos que con el tiempo se cimentaron en las prácticas locales.

Es interesante notar que, según señalan las diferentes pistas aquí expuestas, es en Medellín donde se configura una versión musical de la nación, que tiene como una de sus características fundamentales el blanqueamiento y la depuración de los elementos afro e indígenas presentes en tales estéticas, donde, simultáneamente, se formulan prácticas corporales que acaban transformán-

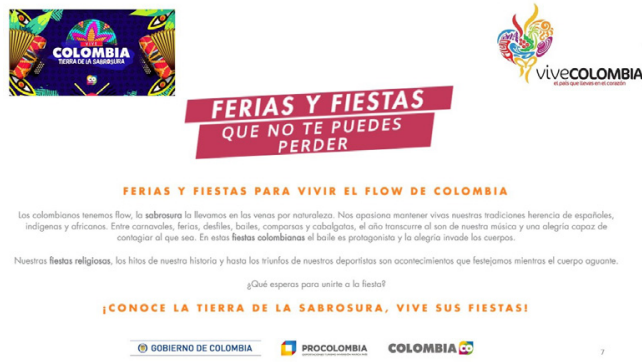

Anuncio publicitario de la campaña de las entidades encargadas de la promoción del turismo e inversión extranjera en el país ${ }^{29}$ dose en versiones coreográficas de las danzas locales, fuertemente influenciadas por géneros de otras procedencias - en este caso concreto, el tango argentino. Esto por sí solo, merecería una reflexión que desborda las pretensiones del trabajo que presento aquí.

Nótese en la pieza publicitaria anterior el apelo directo a la danza, como trazo distintivo de la colombianidad:

Ferias y fiestas que no te puedes perder. Ferias y fiestas para vivir el flow ${ }^{30}$ de Colombia. Los colombianos tenemos flow, la sabrosura ${ }^{31}$ la llevamos en las venas por naturaleza. Nos apasiona mantener vivas nuestras tradiciones, herencia de españoles, indígenas y africanos. Entre carnavales, ferias, desfiles, bailes, comparsas y cabalgatas, el año transcurre al son de nuestra música y una alegría capaz de contagiar al que sea. En estas fiestas colombianas, el baile es protagonista y la alegría invade los cuerpos. Nuestras fiestas religiosas, los hitos de nuestra historia y hasta los triunfos de nuestros deportistas, son acontecimientos que festejamos mientras el cuerpo aguante. ¿Qué esperas para unirte a la fiesta? ¡Conoce la tierra de la sabrosura, vive sus fiestas!" (énfasis míos).

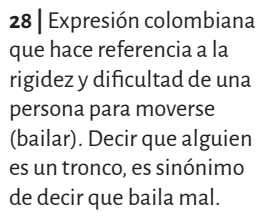

29| Disponible en: http:// www.colombia.travel/es/ ferias-y-fiestas (revisado el 2 de junio de 2020).

30| Anglicismo que se refiere en el contexto a la fluidez del movimiento.

31 Esta expresión se refiere al gusto, sabor y placer en la danza, una traducción aproximada al portugués, sería "gostosura". 
No sorprende entonces, que una fiesta de personas mayores, realizada en un club privado de la ciudad de Medellín, esté antecedida por un discurso que exalta el carácter nacional de aquello construido y reforzado desde lo local. Es por esto, que aquí busco ofrecer datos para una mejor comprensión del papel de esta dimensión estética, su carácter estratégico poético y político en la construcción de imágenes e identidades regionales y nacionales, buscando pistas para entender la actual hegemonía 'paisa' en el plano político nacional.

Para Pacheco (2009), la danza es un rico campo de producción de imágenes que se revelan como dramaturgias singulares, donde el cuerpo se torna propositor de discursos. Para el caso de la Música Bailable o chucu-chucu, se trata de discursos de cuerpos que pretenden ser caribe, depuradamente a la 'paisa'. Aquí, la danza se revela como lugar privilegiado de observación y análisis de los mensajes que vehicula, de las imágenes y de los discursos que construyen simultáneamente el entorno en el que ocurren y a las personas que las practican.

A través de la fiesta, la música y la danza, los cuerpos son vehículos de valores y sentidos, modelados por las estéticas dominantes que configuran una visión de mundo. Autores como Wade (2002) y Pardo (2009), evidencian esto en sus trabajos, así como las disputas que reflejan, construyen y modelan las identidades y las relaciones inter e intra étnicas. Para los casos brasileño y argentino, esto ha sido descrito en las investigaciones de Menezes Bastos (1995, 2005, 2007), Lacerda (2011), Oliveira (2009), Coelho (2009), Domínguez (2009) y Marcon (2014), quienes abordan a partir de géneros como la samba, la música sertaneja, el tango, la milonga, la murga, el candombé y el chamamé, la construcción de identidades regionales y nacionales. Todos estos géneros, dígase de paso, bailables.

Siguiendo a García (2016b), adopto su afirmación de que la danza sería el arte de memorizar, de entrenar y de repetir hasta olvidar que sabemos. Según la autora, en la danza se localizan redes emotivas que pueden ser evocadas con facilidad para recrear lo común como experiencia personal. Como nación olvidamos -o desconocemos- la procedencia de aquello que sabemos. La danza, produciría la experiencia estética de ser parte de la nación mediante actos creativos que actualizan el pasado. Esos actos creativos serían los movimientos que conocemos sin saber exactamente por qué o de donde, serían formas de conocer que encadenan pasado y presente como dejavu - , dice Carcía, que nos permiten transitar la sensación de haber sido esto antes.

Segundo la autora:

Etnografías de finales del XX y lo que va del XXI han venido demostrando cómo en la danza se articulan, mantienen, reformulan y negocian identidades étnicas, raciales, religiosas y de género como lo señala Carozzi...Numerosas etnografías demuestran cómo ideologías políticas de los gobernantes son determinantes en la selección de danzas nacionales (énfasis míos). 
Propongo que se trata de prácticas que cuentan con el poder de afectar emotivamente la experiencia. Algo semejante a lo ocurrido con el fenómeno del fútbol y las coreografías de los jugadores de la selección Colombia en la copa de 2014 (Larraín, 2015), y a aquello que refiere Hernández (2014), respecto al carácter emotivo de la música:

\footnotetext{
En cada encuentro del oyente con la música se produce una acumulación de significados y asociaciones que, con diferentes reiteraciones se van sedimentando en los materiales sonoros, cargándolos de un sentido particular que, a través de la comunicación intersubjetiva, se puede convertir además en un referente cultural. Es por esto que la música, al ser usada como símbolo (como en los himnos nacionales, por ejemplo), puede evocar imágenes y emociones que trascienden el sentido del texto poético [...]; si la música, como lenguaje no verbal, es capaz de evocar emociones y orientar la acción de una forma no evidente y no racional, no es exagerado decir que su dimensión política ha sido subestimada por las disciplinas interesadas en el estudio del poder (Hernández, 2014).
}

\section{A MODO DE CONCLUSIÓN (IDEAS Y REFLEXIONES ABIERTAS)}

En este trabajo busqué aproximarme a la comprensión de formas concretas del regionalismo inscritas en los cuerpos y en los movimientos, para pensar la reciente primacía política 'paisa' y cómo ésta ha venido determinando de muchas formas los rumbos de la nación. Si como propongo, existe un modo 'paisa' de hacer música, danzary festejar, que se ha diseminado por el país, quise explorar cómo es que esto se manifiesta, modela o incide en la política actual.

Intenté mostrar que a ese modo 'paisa', están asociados valores morales, éticos y estéticos que tienen que ver con aquello a partir de lo cual lo 'paisa' ha sido descrito y asociado (trabajo, emprendimiento y religión). Es decir, que esa música, danza y fiesta a la 'paisa' en la versión de sus ejecutantes y voces oficiales, revela un universo de prácticas segregacionistas y con pretensiones hegemónicas, compatibles completamente con lo que ha sido la política electoral de los últimos tiempos en Colombia, donde se ha revelado un conservadorismo que resuena con figuras políticas como Álvaro Uribe Vélez (y sus afines).

En los últimos cinco años, esto ha sido evidente en: 1. la votación negativa respecto a los acuerdos de paz; 2 . la elección como presidente del candidato indicado por Álvaro Uribe Vélez (Iván Duque - sin ninguna trayectoria política importante hasta ahora-), y más recientemente, 3. la pérdida de la votación del plebiscito anticorrupción, que buscaba establecer mecanismos de control contra las prácticas de corrupción en el país. En los tres casos, Antioquia, fue el departamento que determinó las votaciones, manteniendo una posición conservadora y aliada a tendencias 
de derecha. Antioquia votó contra los acuerdos de paz; eligió como presidente a un político sin trayectoria - porque Uribe así lo indicó ${ }^{32}$ - y se opuso a mecanismos más certeros de control contra la corrupción.

La más reciente evidencia de situaciones de este tipo, fue la polémica generada por el proyecto de Ley que se presentó ante el Congreso Nacional el pasado 13 de mayo de 2020, donde se buscaba la elección del carriel — objeto que hace parte del atuendo o traje típico 'paisa'-, como símbolo nacional. La polémica surgió por parte de senadores de la oposición quienes manifestaron que en plena pandemia debía haber prioridades respecto a los proyectos de ley que se presentaban. El proyecto del carriel, que tiene como uno de sus proponentes al expresidente y ahora senador, Álvaro Uribe, polarizó las opiniones entre aquellos que no lo consideraron prioritario por la situación de emergencia que vive el país (y el mundo) y quienes se sintieron ofendidos profundamente porque se hubiera cuestionado la relevancia de nombrar al carriel (símbolo 'paisa') como símbolo nacional ${ }^{33}$.

Pero, ¿cuál es la relación de esto con la fiesta, la música y la danza? Propongo que tanto esa posición política conservadora con tendencia a la derecha, como ciertas formas de hacer música, danzar y festejar — junto con sus soportes estéticos - , son prácticas enraizadas e incorporadas de tal forma en las actividades de socialidad cotidianas en el país, que de hecho es difícil — por no decir imposible — que no haya cierta resonancia entre ellas, porque apelan al sentido de identificación y pertenencia a un colectivo.

Siguiendo a Taylor (2013), me atrevería a decir que eventos como los señalados aquí (música, danza, fiesta, etc.) funcionarían como enunciados - en el sentido atribuido por Bakhtin (1979) — una vez que, en tanto exhibiciones públicas, harían parte de una cadena discursiva que mediante actos ceremoniales ilustran hasta qué punto el performance (puesta en escena) y la política, hacen uso de repertorios culturales reconocidos como prácticas de legitimación - aunque eventualmente puedan sobreponerse y ser contestados.

En ese sentido, vale la pena mencionar aquí el trabajo de Oliveira (2014) ${ }^{34}$, donde el autor reflexiona sobre la acusación de apoliticidad que históricamente ha sufrido la música popular, en particular por una característica que le es inherente en algunos contextos: su vínculo con la danza. Oliveira explica de forma notable, que la apoliticidad atribuida a muchos géneros de la música popular se debe a que se bailan y tratan de temas amorosos y eróticos (aspectos de dominio de lo privado). Oponiéndose a tal acusación, Oliveira afirma que la danza puede verse también como una afirmación de la existencia de determinados grupos sociales, que muchas veces son invisibles por medio de otros códigos ${ }^{35}$. El autor sugiere pensar la música popular y sus danzas, como afirmación de un punto de vista que no niega la existencia del otro, como "política que no niega la diferencia, sino que, evita al Estado".
32 | En la época de elecciones presidenciales, era común que los seguidores de Uribe -ante la imposibilidad de un nuevo mandato suyo- manifestaran abiertamente que votarían "por el que diga Uribe".

33 |Ver más en: https://www. elpais.com.co/colombia/ polemica-por-proyecto-deley-para-convertir-carrielantioqueno-en-patrimonionacional.html (revisado el 2 de junio de 2020). https://www.elespectador com/noticias/politica/ proyecto-que-consagra-alcarriel-como-patrimonio-lamanzana-de-la-discordiaen-la-camara-articulo-919818 (revisado el 2 de junio de 2020).

34| Agradezco la gentileza de mi amigo y colega Allan de Paula Oliveira, por haber compartido conmigo este texto antes de que saliera publicado.

35 | Es pertinente pensar esto para el caso del reggaetón en Medellín y las relativamente recientes iniciativas de visibilización de la población negra en Colombia, en condiciones de gran marginalidad, que han tenido en la danza un espacio propicio para darse a conocer: Ver por ejemplo: https:// www.wradio.com.co/noticias/ internacional/jovenes-dela-region-colombiana-delchoco-enfrentan-la-violenciacon-el-baile/20171202/ nota/3654461.aspx (revisado el 2 de junio de 2020). 
Estas reflexiones son valiosas para pensar los trabajos más recientes desarrollados en Colombia sobre las músicas del caribe, pues muchos exploran la dimensión política de los géneros, pero vinculada a una idea de intento hegemónico del Estado; por ejemplo, Figueroa (2009), que es enfático en subrayar la instrumentalización de la música del Caribe, particularmente del vallenato, en la construcción de un proyecto nacional por partede las élites políticasy económicasy suvinculación con el paramilitarismo en aquella región de Colombia; y Blanco (2009), que denuncia el proyecto de disfrazar las profundas problemáticas de la nación, promoviendo una imagen festiva a través de musicalidades del caribe.

Es pertinente aclarar, que las reflexiones aquí presentadas no pretenden ser vistas como versión unificadora del regionalismo 'paisa', sino intentar evidenciar esa visión consensuada que existe de él, así como sus pretensiones totalizadoras, para entender la pertinencia y la efectividad de determinadas estéticas en un contexto como el colombiano, reconociendo que si bien no se puede negar la existencia de un proyecto de reivindicación regional, el consumo cultural, nunca es pasivo, es decir, esta atravesado por oposiciones, disensos, disputas y narrativas contrahegemónicas ${ }^{36}$.

Finalmente, quiero señalar que la irrupción de los modos 'paisas' en el contexto colombiano, que tuvo en la música y en la danza una estrategia eficaz, podría pensarse como un aspecto aliado a la actual hegemonía política nacional. Me explico: sabemos danzar — sin saber muy bien cómo aprendimos - (las formas y los contenidos de nuestra experiencia sensorio-motriz como nación, se aproximan). Los discursos políticos que resuenan con la ética y la estética; con los valores y con la moral que se reconoce propia, parecen familiares: "al son que me toquen bailo37", dicta el refrán.

Así, a partir de una presencia nacional garantizada — vía los referentes culturales compartidos - es más fácil convencer y adherir, pues el discurso político va a generar sintonías en aquello que es familiar, que sin saber explicar exactamente cómo, conocemos, hace parte del habitus (Bourdieu, 2007 [1979]), fue apropiado de forma inconsciente y funciona como estructura estructurante, pues se aprendió por el cuerpo en un proceso de familiarización práctica compartido por varias generaciones de una nación. Podría decirse que: ¿Música y danza (a la 'paisa') abonaron el terreno para una hegemonía política conservadora tendiente a la derecha en Colombia?, ¿o viceversa?.

América Larraín es profesora asociada de la Universidad Nacional de Colombia, sede Medellín.

CONTRIBUCIÓN DE AUTORIA: Este artículo se desarrolló en el marco de un posdoctorado que cursé en 2018 en la Universidad Federal de Santa Catarina - Brasil,
36 | Aquí podría hablarse del reggaetón como ejemplo de esos disensos que contestan los valores morales asociados a la antioqueñidad, o de la más reciente `Guaracha Electrónica', zapateo o aleteo; un subgénero electrónico, que teniendo por base ritmos latinos, ha venido cobrando fuerza en el país -y fuera de él-. Considero que este ámbito estético merece ser explorado como movimiento contrahegemónico de disenso, como política, en el sentido atribuido por Oliveira (2014); esa política que evita al Estado y reivindica el cuerpo y la danza; que es una declaración, una forma de hacer visible la existencia de ciertos grupos sociales.

37| Esta expresión hace alusión a que se sigue la instrucción dada, se obedece un mandato. 
bajo la supervisión del profesor Rafael José de Menezes Bastos, a quien agradezco la generosa orientación y comentarios que contribuyeron al desarrollo de las ideas aquí planteadas. La estancia posdoctoral que tuvo como resultado este artículo, se dio gracias a la financiación de la Convocatoria Nacional para el apoyo a la movilidad internacional de la Universidad Nacional de Colombia 2017-2018.

FINANCIACIÓN: No se aplica

\section{REFERENCIAS BIBLIOGRÁFICAS}

ACOSTA, Marisol. 2014. "Jóvenes de Medellín, nuevos actores sociales, 1960-1970". Pensar Historia, v. 4: 21-36. https://revistas.udea.edu.co/index.php/ pensarh/article/view/20843/17447

ARCILA Estrada, María T. 2006. "El elogio de la dificultad como narrativa de la identidad regional en Antioquia". Historia Critica, v. 32: 38-66. http://www. scielo.org.co/pdf/rhc/n32/n32a03.pdf

BAKHTIN, Mikhail. 1979. La estética de la creación verbal. Siglo XXI Editores, Madrid.

BERMÚDEZ, Egberto. 2006. "Del humory El amor; Música de parranda y música de despecho en Colombia 1". Revista Cátedra de Artes 3: 81-108.

BERMÚDEZ, Egberto. 2007. “Del humory El amor; Música de parranda y música de despecho en Colombia 2". Revista Cátedra de Artes 4: 63-89.

BLANCO, Darío. 2009. “De melancólicos a rumberos... de los Andes a la costa. La identidad colombiana y la música caribeña". Boletín de Antropología Universidad de Antioquia, 23 (40): 102-128. Disponible en https://revistas.udea.edu. co/index.php/boletin/article/view/6477
BOURDIEU, Pierre. [1979] 2007. A distinção: crítica social do julgamento. São Paulo, EDUSP.

CANCILLERÍA COLOMBIA. 2016. Cartilla Pedagógica del acuerdo fina". Disponible en https://www.cancilleria.gov.co/sites/default/ files/cartillaabcdelacuerdofinal2.pdf

CASTAÑEDA, Sebastián. 2019. La construcción de la estética de la mujer a partir del fenómeno del narcotráfico em Colombia. Bogotá, Universidad Santo Tomás. Disponible en https://repository.usta.edu.co/bitstream/ handle/11634/21283/2020sebastiancastaneda. pdf? sequence $=2$ \&isAllowed $=y$

COELHO, Luis Fernando Hering. 2009. Os músicos transeuntes: de palavras e coisas em torno de uns batutas. Santa Catarina, tese de doutorado. Universidade Federal de Santa Catarina. Disponible en http://repositorio. ufsc.br/xmlui/handle/123456789/92380

CORREA, Didier. 2014. Medellín: instantáneas del narcotráfico. Medellín, Colombia, tesis de Maestría en Estética, Universidad Nacional de Colombia. Disponible en http://bdigital. unal.edu.co/46697/1/98712591.2014.pdf.pdf

DOMINCUEZ, Maria Eugenia. 2009. Suena el Río: Entre tangos, milongas, murgas e condombés: músicos e gêneros rio-platenses em Buenos 
Aires. Santa Catarina, tese de doutorado, Universidade Federal de Santa Catarina. Disponible en https://repositorio. ufsc.br/handle/123456789/92438

DUQUE Suárez, León. 2018. El mes de la parranda: el papel de la música parrandera en el Valle de Aburrá durante las festividades decembrinas. Medellín, Colombia, maestría en Antropología, Universidad de Antioquia. Disponible en http://bibliotecadigital. udea.edu.co/bitstream/10495/10032/1/ DuqueLeon_2018_MesParrandaPapel.pdf

EL ESPECTADOR. 2019. Colombia: el país con más desplazados del mundo. Disponible en https://www.elespectador. com/colombia2020/pais/colombiael-pais-con-mas-desplazadosdel-mundo-articulo-866644

EL ESPECTADOR. 2020. Proyecto que consagra al carriel como patrimonio, la manzana de la discordia en la Cámara. Disponible en https://www.elespectador.com/noticias/ politica/proyecto-que-consagra-al-carrielcomo-patrimonio-la-manzana-de-ladiscordia-en-la-camara-articulo-919818

EL PAIS. 2018. Cuando en Cali se censuró la salsa de Richie Ray y Bobby Cruz. Disponible en https://www.elpais. com.co/entretenimiento/cultura/ cuando-en-cali-se-censuro-la-salsade-richie-ray-y-bobby-cruz.html

EL PAIS. 2020. Polémica por proyecto de ley para convertir carriel antioqueño en patrimonio nacional. Disponible en https://www. elpais.com.co/colombia/polemica-porproyecto-de-ley-para-convertir-carrielantioqueno-en-patrimonio-nacional.html

FIGUEROA, José Antonio. 2009. Realismo mágico, vallenato y violencia política en el Caribe Colombiano. Bogotá, Instituto Colombiano de Antropología e Historia (ICANH).
GARCÍA Schlegel, María Teresa. 2016a. "El mapalé de Sonia Osorio. Todos somos uno, felices y copulando". Revista Calle 14, N.11 (19): 86-93. Disponible en https://revistas.udistrital. edu.co/index.php/c14/article/view/11075

GARCÍA Schlegel, María Teresa. 2016b. La fémina y la danza como experiencia de Nación. Colombia, tesis de doctorado en Antropología. Universidad Nacional de Colombia. Disponible en http://bdigital. unal.edu.co/52254/1/39685668.2016.pdf

HERNÁNDEZ Salgar, Óscar. 2014. Los mitos de la música nacional. Poder y emoción en las músicas populares colombianas 1930-1960. Bogotá, tesis de doctorado en Ciencias Sociales y Humanas, Pontificia Universidad Javeriana. Disponible en https://repository. javeriana.edu.co/handle/10554/15410

HOSOKAWA, Shuhei. 1997. "Salsa no tiene frontera: Orquesta de la Luz or the Globalization and Japanization of AfroCaribbean Music". TRANS - Revista Transcultural de Música. Disponible en http://www.sibetrans. com/trans/articulo/266/salsa-no-tiene-fronteraorquesta-de-la-luz-or-the-globalizationand-japanization-of-afro-caribbean-music

LACERDA, Izomar. 2011. Nós somos batutas: uma antropologia da trajetória do grupo musical carioca Os Oito Batutas e suas articulações com o pensamento musical brasileiro. Brasíl, Florianópolis, dissertação de mestrado, Universidade Federal de Santa Catarina. Disponible en https://repositorio.ufsc. br/xmlui/handle/123456789/95647

LARRAIIN, América. 2015. "Bailar fútbol: reflexiones sobre el cuerpo y la nación en Colombia", Boletín de Antropología Universidad de Antioquia, 30 (50): 191-207. Disponible en https://revistas.udea.edu. co/index.php/boletin/article/view/25278

LARRAÍN, América y MADRID, Pedro. 2020. "Aproximaciones al discurso de paisa en 
Colombia". Revista Virajes Universidad de Caldas, 22 (2): 185-209. https://doi. org/10.17151/rasv.2020.22.2.8

MARCON, Fernanda. 2014. Los viajes del río: Migração, festa e alteridade entre Chamameceiros e chamameceiras das províncias de Buenos Aires, Corrientese Entre Ríos, Argentina. Santa Catarina, tese de Doutorado em Antropologia Social, Universidade Federal de Santa Catarina: https://repositorio. ufsc.br/handle/123456789/123240

MARCUS, George. 2001. "Etnografía en/ del sistema mundo. El surgimiento de la etnografía multilocal" Alteridades, 11 (22): 111-127. Disponible en https://www. redalyc.org/pdf/747/74702209.pdf

MENEZES BASTOS, Rafael José de. 1995. "A origem do samba como invenção do Brasil (porque as canções têm música?)", Revista Brasileira de Ciências Sociais, 31, 156177. Disponible en http://www.anpocs. com/images/stories/RBCS/rbcs31_09.pdf

MENEZES BASTOS, Rafael José de. 2005. "Les Batutas, 1922: uma antropologia da noite parisiense." Revista Brasileira de Ciências Sociais, 20 (58): 178-213. Disponible en https://www.scielo.br/scielo.php?pid= S010269092005000200009\&script=sci_ abstract\&tlng=pt

MENEZES BASTOS, Rafael José de. 2007. "Para uma antropologia histórica das relações musicais Brasil/Portugal/África: o caso do fado e sua pertinência ao sistema de transformações lundu-modinha-fado." Antropologia em Primeira Mão, 102, pp. 1-14.

OLIVEIRA, Allan de Paula. 2009. Miguilim foi pra cidade ser cantor: uma antropologia da música sertaneja. Brasil, Florianópolis, tese de doutorado, Universidade Federal de Santa Catarina. Disponible en https:// repositorio.ufsc.br/handle/123456789/92786
OLIVEIRA, Allan de Paula. 2014. "Pump up the Jam: Música Popular e Política”. In: Arte e Política no Brasil. Modernidades. André Egg et al (orgs.). Editora Perspectiva, São Paulo, pp. 315-348.

OLIVEN, Ruben George. 2006. A parte e o todo: A diversidade cultural no Brasilnação, 2a. edição. Petrópolis (Coleção Identidade brasileira), Editora Vozes.

PACHECO, Laura. 2009. "Imagens do corpo, dança e performatividade". Anais da V Reunião Científica de Pesquisa e Pós-graduação em Artes Cênicas.

PARDO, Mauricio. 2009. Música y sociedad en Colombia: Traslaciones, legitimaciones e identificaciones. Universidad del Rosario.

PARRA, Juan Diego. 2014. Arqueología del Chucu-chucu: la revolución sonora tropical urbana antioqueña. Medellín, años 60 y 70 . Instituto Tecnológico Metropolitano, Medellín.

PARRA, Juan Diego. 2017. Deconstruyendo el Chucu-chucu. Auges, declives y resurrecciones de la música tropical colombiana. Instituto Tecnológico Metropolitano, Medellín.

WADE, Peter. 1999. Gente negra, Nación mestiza: dinámicas de las identidaders raciales en Colombia. Historia y sociedad, [S. I.], n. 6: 273-275, 1999. Disponível em: https:// revistas.unal.edu.co/index.php/hisysoc/article/ view/23132. Acesso em 17 de fevereiro de 2021.

WADE, Peter. 2002. Música Raza y Nación. Música tropical en Colombia. Vicepresidencia de la República de Colombia, Departamento Nacional de Planeación, Programa Plan. Caribe.

WADE, Peter. 2011. "Multiculturalismo y racismo". Revista Colombiana de Antropología 47 (2): 15-35. DOI: https:// doi.org/10.22380/2539472X.956 


\section{MATERIALES CONSULTADOS}

BBC, 2013. Del tango al reggaetón:

Medellín, capital de los contrastes musicales: https://www.bbc.com/mundo/ noticias/2013/11/131017_cultura_medellin_ capital_musical_colombia_jgc

DANE, 2018. Censo Nacional de Población y Vivienda. https://www.dane.gov.co/ index.php/estadisticas-por-tema/ demografia-y-poblacion/censo-nacionalde-poblacion-y-vivenda-2018

MINISTERIO DE CIENCIAS COLOMBIA. 2016. Colombia, el segundo país más biodiverso del mundo: https://minciencias.gov.co/ sala_de_prensa/colombia-el-segundopais-mas-biodiverso-del-mundo

SEMANA, 2017. Medellín, a ritmo de reguetón. Disponible en https://www. semana.com/cultura/articulo/medellinla-meca-del-regueton/551877
WIKIPEDIA. 2012. Mapa de la región cultural Paisa. Disponible en https://es.wikipedia.org/wiki/ Archivo:Mapa_de_la_Regi\%C3\%B3n_Paisa.svg

WRADIO. 2017. Jóvenes de la región colombiana del Chocó enfrentan la violencia con el baile. Disponible en https://www.wradio.com.co/ noticias/internacional/jovenes-de-la-regioncolombiana-del-choco-enfrentan-la-violenciacon-el-baile/20171202/nota/3654461.aspx

YOUTUBE. 2013. Lucho, el documental: https:// www.youtube.com/watch?v=uEWGnFjnjXs

YOUTUBE. 2018. Cuando el Chucu Chucu se vistió de Frac: https://www.youtube. com/watch?v=r1_RRyxjCGo

YOUTUBE. 2011. Baile de Uribe: https://www. youtube.com/watch?v=JybxKPmXr3Y

YOUTUBE. 2011. Los últimos videos del Mono Jojoy: https://www.youtube.com/watch?v=Ikqlh__icjY

Recebido em 15 de outubro de 2018. Aceito em 22 de setembro de 2020. 